\title{
ŹRÓDLA ARCHEOLOGICZNE DO DZIEJÓW DRUKARSTWA NA PRZYKŁADZIE DRUKARNI Z OSTROWA TUMSKIEGO W POZNANIU
}

\author{
ARCHAEOLOGICAL EVIDENCE OF THE HISTORY \\ OF PRINTING ON THE BASIS OF PRINTING HOUSES \\ IN OSTRÓW TUMSKI IN POZNAŃ
}

\author{
Olga Antowska-Goraczniak \\ Instytut Prahistorii, Uniwersytet im. Adama Mickiewicza \\ ul. Umultowska 89D, 61-614 Poznań, Poland \\ olgaag@amu.edu.pl
}

\begin{abstract}
The article presents the results of archaeological and architectural investigations that have been carried out within a former printing house at the Lubrański's Academy in Ostrów Tumski in Poznan, together with a collection of lead pieces of type collected between 2002 and 2014. Archaeological evidence serves as a pretext for revising the history of printing houses operating in the area since the turn of the seventeenth century towards the end of the eighteenth century.
\end{abstract}

KEY WORDS: printing, type, Poznań, Lubrański’s Academy, Academic Printing House.

Dotychczasowe opracowania archeologiczne nowożytnych materiałów źródłowych $\mathrm{z}$ terenu ziem polskich pomijały przedmioty związane $\mathrm{z}$ drukarstwem, zapewne wskutek braku rejestrowania tego typu artefaktów w badaniach wykopaliskowych. Podczas badań archeologicznych i prowadzonych nadzorów na terenie Ostrowa Tumskiego w Poznaniu w latach 2006-2008 1 udało się pozyskać i zidentyfikować liczną serię czcionek drukarskich (tab. 1; ryc. 1). Zdecydowana większość ma-

\footnotetext{
${ }^{1}$ Omawiane materiały pochodzą przede wszystkim z badań Instytutu Prahistorii UAM prowadzonych przez prof. H. Kóčkę-Krenz z lat 2002-2008. Materiały i dokumentacja IP UAM.
} 
Tabela 1. Rozmieszczenie ilościowe czcionek na posesjach Ostrowa Tumskiego w Poznaniu. Uwzględniono również matrycę ozdobną $(+)$ oraz puste (czcionki?) mosiężne $(*)$

Table 1. Quantitative distribution of the pieces of type within the residential area in Ostrów Tumski in Poznań. A decorative matrix (+) and empty brass (*) (pieces of type?) have also been included

\begin{tabular}{|c|c|c|c|}
\hline Stanowisko & Numer wykopu/sondażu (suma czcionek) & $\begin{array}{c}\text { Warstwa/ } \\
\text { obiekt }\end{array}$ & $\begin{array}{c}\text { Liczba } \\
\text { czcionek }\end{array}$ \\
\hline \multirow{3}{*}{$\begin{array}{l}\text { Ul. Lubrańskiego } 1 \text { (badania } \\
\text { ratownicze pod fundamenty } \\
\text { pomnika - 2002) }\end{array}$} & \multirow{3}{*}{ Sondaż 2 od strony wschodniej (7) } & IV & $1 *$ \\
\hline & & $\mathrm{V}$ & 5 \\
\hline & & VI & 1 \\
\hline \multirow{5}{*}{$\begin{array}{l}\text { Akademia Lubrańskiego } \\
\text { (AL1 - 2006) }\end{array}$} & Wykop 1 - piwnica NE (1) & III & 1 \\
\hline & Wykop 3 - piwnica NE (1) & II & 1 \\
\hline & Wykop 4 - skrzydło zachodnie - parter (1) & II & 1 \\
\hline & \multirow{2}{*}{ Wykop 14 - skrzydło zachodnie - parter (2) } & Ob. 2 & 1 \\
\hline & & $\mathrm{I}$ & 1 \\
\hline \multirow{6}{*}{$\begin{array}{l}\text { Akademia Lubrańskiego - } \\
\text { nadzory (AL1 - 2006) }\end{array}$} & \multirow{4}{*}{ Sondaż I przy południowej fasadzie (15) } & I wm* & 1 \\
\hline & & II wm & $2+$ \\
\hline & & III wm & $8 *$ \\
\hline & & IV wm & 4 \\
\hline & Sondaż L przy północnej fasadzie(1) & hałda & 1 \\
\hline & Sondaż M przy północnej fasadzie (2) & III wm & 2 \\
\hline \multirow{10}{*}{$\begin{array}{l}\text { Akademia Lubrańskiego } \\
\text { (AL1 - 2007) }\end{array}$} & \multirow{6}{*}{ Wykop I przy fasadzie zachodniej (16) } & IX & 1 \\
\hline & & Wkop A (X) & 2 \\
\hline & & Wkop A (XI) & 1 \\
\hline & & $\mathrm{XI}$ & 5 \\
\hline & & XII & 3 \\
\hline & & hałda & 4 \\
\hline & \multirow{4}{*}{$\begin{array}{l}\text { Wykop II przy narożu } \\
\text { południowo-zachodnim (17) }\end{array}$} & IV & 4 \\
\hline & & $\mathrm{V}$ & 1 \\
\hline & & VI & 10 \\
\hline & & hałda & 2 \\
\hline \multirow{4}{*}{$\begin{array}{l}\text { Akademia Lubrańskiego } \\
\text { (AL1 - 2008) }\end{array}$} & \multirow{3}{*}{ Wykop IV po stronie północnej (21) } & IV & 1 \\
\hline & & Wkop C (IV) & 1 \\
\hline & & $\mathrm{V}$ & 19 \\
\hline & Wykop V po stronie północnej (3) & $\mathrm{V}$ & 3 \\
\hline $\begin{array}{l}\text { U1. Posadzego } 5 \\
\text { (P5 - 2006) }\end{array}$ & Wykop IV (1) & II & 1 \\
\hline $\begin{array}{l}\text { U1. Posadzego } 7 \\
(\mathrm{P} 7-2009)\end{array}$ & Wykop 1 (2) & IIIb & 2 \\
\hline Ostrów Tumski 4 (2009) & Wkop pod kanalizację (1) & hałda & 1 \\
\hline Ostrów Tumski 10 (2004) & Wykop $31(1)$ & IIa & 1 \\
\hline \multirow{2}{*}{$\begin{array}{l}\text { Ostrów Tumski } 11 \\
\text { (OT11-2014) }\end{array}$} & Wykop IIIb (1) & IIIb & 1 \\
\hline & Wykop V (1) & II & 1 \\
\hline
\end{tabular}

${ }^{*}$ wm - warstwa mechaniczna 


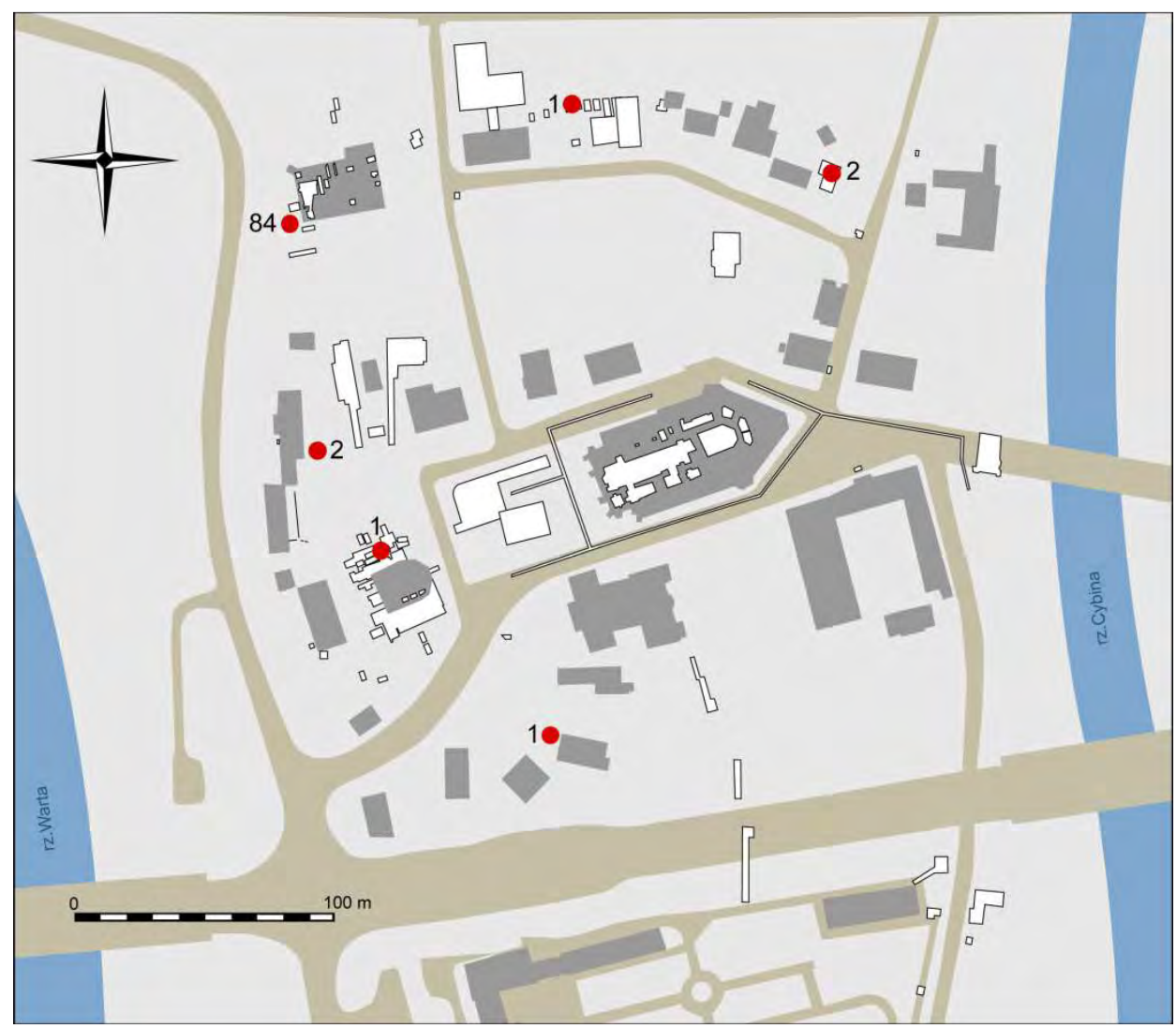

Ryc. 1. Plan Ostrowa Tumskiego z zaznaczeniem liczby czcionek drukarskich pozyskanych podczas badań archeologicznych (rys. W. Gorączniak)

Fig. 1. The plan of Ostrów Tumski indicating the number of pieces of type collected during the archaeological excavations (by W. Gorączniak)

teriału typograficznego została odkryta w najbliższym otoczeniu dawnej Akademii Lubrańskiego. Okazało się wówczas, że już wcześniej - w 2002 r. - znaleziono pojedyncze egzemplarze ołowianych czcionek. Ponieważ był to tzw. ślepy materiał zecerski albo połamane, zniszczone fragmenty, nie łączono ich z funkcjonującą w pobliżu nowożytną drukarnią. Poza rejonem dawnego kolegium w północno-zachodniej części Ostrowa pojedyncze egzemplarze ołowianych czcionek odnotowano również na posesji przy ul. Posadzego 5 (1 szt.), przy ul. Posadzego 7 (2 szt.), na posesjach przy ul. Ostrów Tumski 10 przy kościele pw. Najświętszej Marii Panny $(1 \text { szt.), przy ul. Ostrów Tumski } 11 \text { (2 szt. })^{2}$ oraz przy ul. Ostrów Tumski 4

\footnotetext{
${ }^{2}$ Badania archeologiczne prowadzone podczas remontu kanonii w 2014 r. przez firmę Artura Dębskiego „Mos Maiorum”, któremu dziękuję za udostępnienie materiałów.
} 
(1 szt.) $)^{3}$. Pojedyncze czcionki zostały opublikowane w książce popularnonaukowej dotyczącej Akademii Lubrańskiego (Kóčka-Krenz 2007, s. 16-17) lub przy omówieniu zabytków metalowych z badań w rejonie ul. Posadzego (Sikora 2012, s. 206, ryc. $2: 7)^{4}$.

\section{MATERIALY Z BADAŃ ARCHEOLOGICZNYCH}

Łącznie z dotychczasowych badań archeologicznych z Ostrowa Tumskiego pozyskano 91 sztuk ołowianych czcionek drukarskich, domniemane dwie kolejne czcionki wykonane prawdopodobnie $\mathrm{z}$ mosiądzu oraz ozdobną matrycę drukarską. Typowa czcionka drukarska używana jako materiał typograficzny ma kształt prostopadłościanu (tzw. słupek) i zaopatrzona jest w górnej części w główkę z wypukłym negatywem znaku (Sowiński 1988, s. 225-227, ryc. 11-12) (ryc. 2). Płaska powierzchnia główki to tzw. oczko, czyli powierzchnia samego znaku. Jedna z powierzchni
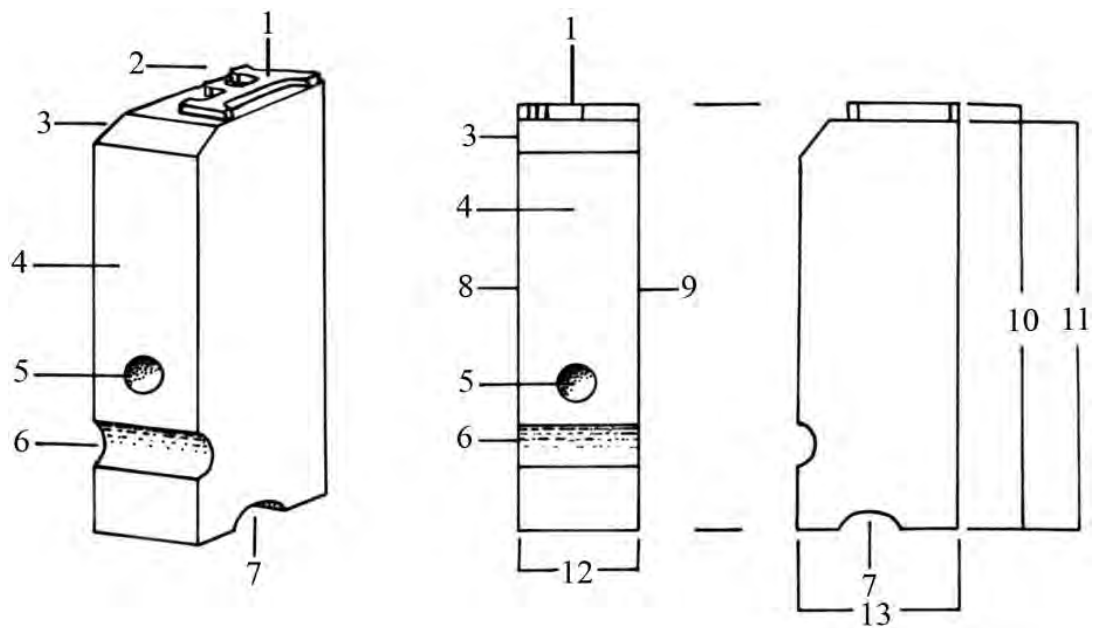

Ryc. 2. Budowa czcionki. Objaśnienia: 1 - oczko, czyli powierzchnia znaku; 2 - główka; 3 - podcięta krawędź przednia główki; 4 - powierzchnia sygnaturowa/przednia; 5 - znakowanie; 6 - sygnatura; 7 - żłobek na spodzie; 8 - bok lewy; bok prawy; 10 - długość słupka z główką; 11 - długość słupka bez główki; 12 - szerokość; 13 - wysokość

Fig. 2. Diagram of a type. Legend: 1 - face; 2 - shoulder; 3 - beard; 4 - body; 5 - marking/labelling; 6 - nick; 7 - groove; 8 - left side; 9 - right side; 10 - length of the body with a face; 11 - length of the body without a face; 12 - width; 13 - point size

${ }^{3}$ Czcionka z hałdy z wykopów założonych podczas prac naprawczych przy kanalizacji, prowadzonych w $2009 \mathrm{r}$.

${ }^{4}$ Tu błędne ustawienie czcionki na rycinie sygnaturą do góry. 
bocznych słupka ma w dolnej części żłobek - sygnaturę. Powierzchnia sygnaturowa służy do poprawnego ułożenia czcionek w ramach podczas przygotowania strony do druku. Wyznacza dół znaków na główce. W omawianym zbiorze tylko 5 czcionek nie ma sygnatury. Czcionki te są nieco krótsze (wysokość 16-21 mm) - prawdopodobnie zostały uszkodzone na wysokości wgłębienia. Temu samemu celowi służy asymetrycznie umieszczony żłobek na spodniej płaszczyźnie czcionki. Na licznych egzemplarzach odnotowano również podcięcia przedniej (ryc. 2:3) lub tylnej albo obu górnych krawędzi oraz niewielkie dołki w ściankach. Prawdopodobnie zabiegi te łączyć można z systemem znakowania poszczególnych kompletów czcionek, a zatem zestawom posiadającym ten sam krój, stopień (wielkość) i odmianę pisma ${ }^{5}$ (choć w niektórych przypadkach nie można wykluczyć również korozji lub błędów przy odlewie). Wysokości zarejestrowanych nieuszkodzonych czcionek wahają się w przedziale od 24 do $25 \mathrm{~mm}$.

\section{Litery, znaki interpunkcyjne, cyfry}

Odnotowano 46 (50,5\%) czcionek służących do pisania. Wśród nich najliczniej wystąpiły różne kroje i wielkości liter (29 egz.). Ze źródeł pisanych wynika, że materiał typograficzny był stosunkowo często uzupełniany w czcionki - zarówno antykwy, jak i kursywy o różnej wielkości i kroju (Sójka 1977a, s. 25-28). Kwerenda barokowych starodruków potwierdziła także częste używanie większej liczby krojów i wielkości liter nawet w obrębie jednej strony. Tę różnorodność obserwuje się w omawianym zbiorze. Trudności sprawia wyodrębnienie czcionek $\mathrm{z}$ tych samych kompletów. W materiale typograficznym wydzielono 17 egzemplarzy pojedynczych czcionek z literami pisanymi antykwą (ryc. 3:1-17). Były to: á, ą, c, F, g, i, J, K, m, $\mathbf{n}, \mathbf{o}, \mathbf{q}, \mathbf{\Gamma}$ (czytane jak s), u, W, z, ż. Czcionka z literą $\mathbf{q}$ i $\mathbf{\int}$ ma przewieszkę, tzn. wystający poza słupek fragment główki. Litera $\mathbf{\Gamma}$ jest bardziej ozdobna, wydaje się pisana gotykiem. Na oczku z literą $\mathbf{n}$ stwierdzono uszkodzenie dolnej części litery. Kolejnych 8 liter wykonano w formie kursywy, czyli pochyłym pismem, są to litery $\boldsymbol{c}$, $\boldsymbol{c}, \boldsymbol{e}, \boldsymbol{i}(2$ egz.), $\boldsymbol{o}$ (2 egz.) oraz $\boldsymbol{w}$ (ryc. 4:1-8). Na czterech czcionkach wystąpiły łączone litery, tzw. ligatury (ryc. 3:18; 4:9-11). Stwierdzono wśród nich zestawienia liter: $\boldsymbol{c t}$ (kursywa), w których dodatkowym łukiem litera $\boldsymbol{c}$ łączy się górą z literą $\mathbf{t}$. Litery $\boldsymbol{c} t$ wydają się pogrubiane. Również w formie kursywy wykonano na oczkach ligatury $\boldsymbol{f f}, \boldsymbol{f} \boldsymbol{k}$ (czytane jak sk) oraz już prostą czcionką ligaturę ft (czytane jak st). $\mathrm{W}$ czcionkach z literami $f f$ oraz $\boldsymbol{f k}$ zastosowano przewieszkę. Prawdopodobnie od kompletu pochodzą czcionki z literami pisanymi antykwą: á, ft i n; kolejny zestaw two-

\footnotetext{
${ }^{5}$ Szczegółowy katalog z danymi metrycznymi i opisowymi poszczególnych czcionek planowany jest w publikacji dotyczącej badań archeologiczno-architektonicznych Akademii Lubrańskiego. Obecnie maszynopis w Instytucie Prahistorii UAM.
} 

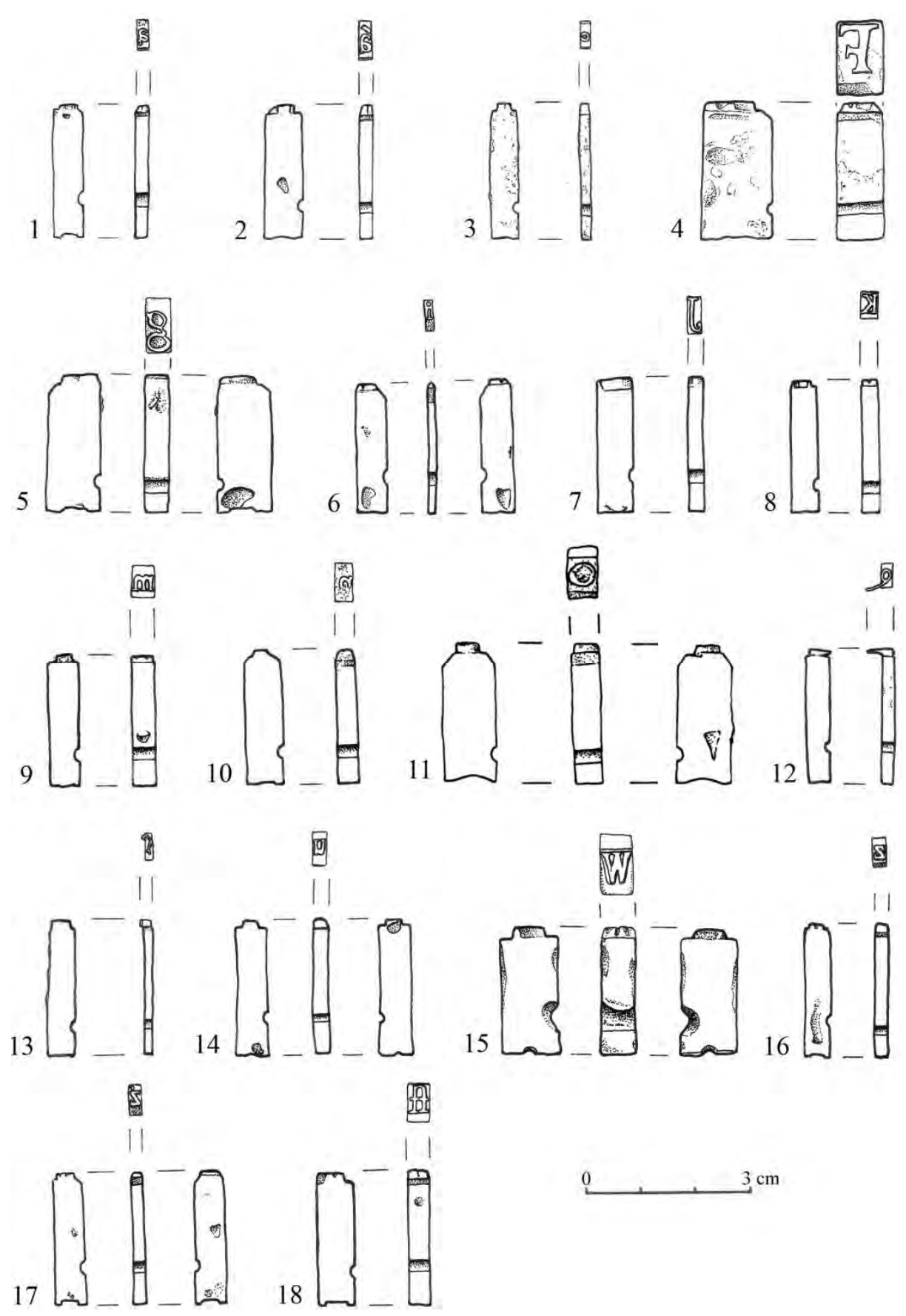

Ryc. 3. Czcionki z literami. Ligatura: 18

Fig. 3. Letters. Ligature: 18 

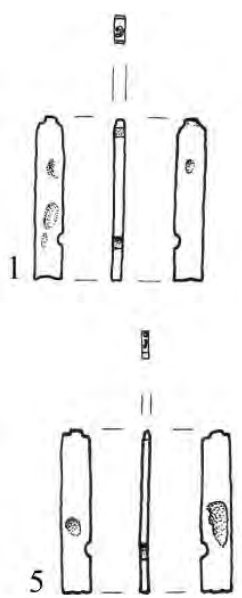
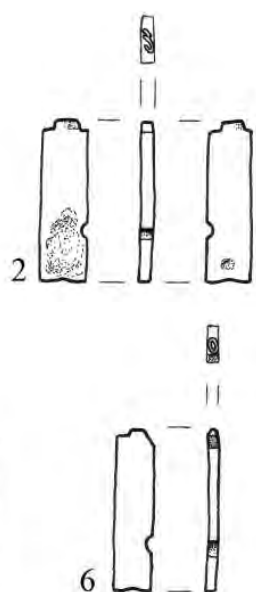
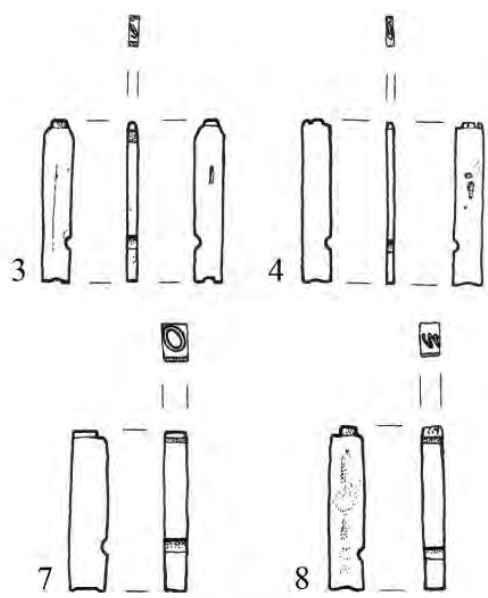
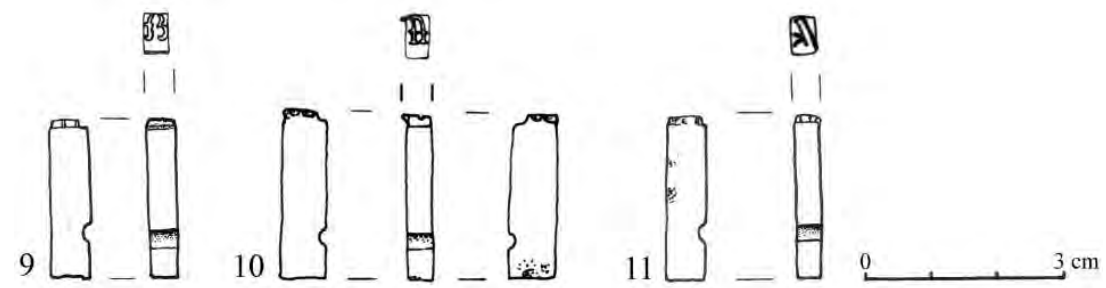

Ryc. 4. Czcionki z literami - kursywy. Ligatury: 9-11

Fig. 4. Italic letters. Ligatures: 9-11

rzą czcionki z literami: $\dot{\mathbf{z}}$ oraz i. Wśród czcionek z kursywą do jednego kompletu należały zapewne te z literami: $\boldsymbol{c}, \boldsymbol{e}, \boldsymbol{i}$; kolejny dają czcionki z literami $\boldsymbol{c} \boldsymbol{t}$ i $\boldsymbol{o}$. $\mathrm{Na}$ 13 czcionkach odnotowano znaki interpunkcyjne (ryc. 5:1-13): / . / (6 egz.), / : / (4 egz.), / , / (2 egz.) i / - / (1 egz.). W starodrukach Drukarni Akademickiej znaki interpunkcyjne oprócz swych podstawowych funkcji w zdaniu używane były do dekoracji ramek i w podkreśleniach wraz z dekoracyjnymi motywami wykonanymi tzw. ozdobnikami. Natomiast 4 czcionki mają na oczkach cyfry (ryc. 5:14-17): cyfra 1 (1 egz.), cyfra 2 (2 egz., w tym jedna pisana kursywą), cyfra 7 (pisana kursywą, 1 egz.). Jedna $\mathrm{z}$ czcionek o nieczytelnym oczku być może przedstawia cyfrę 1 lub literę I (zbiór uszkodzone/nieokreślone).

\section{Ozdobniki}

Bardziej interesującą grupę czcionek stanowią ozdobniki - wykorzystywane w drukach do podkreśleń, ramek, oddzielenia poszczególnych partii tekstu i nadania drukowanej pozycji określonej, spójnej estetyki ( 8 egz. - 8,8\%). W zachowanych 

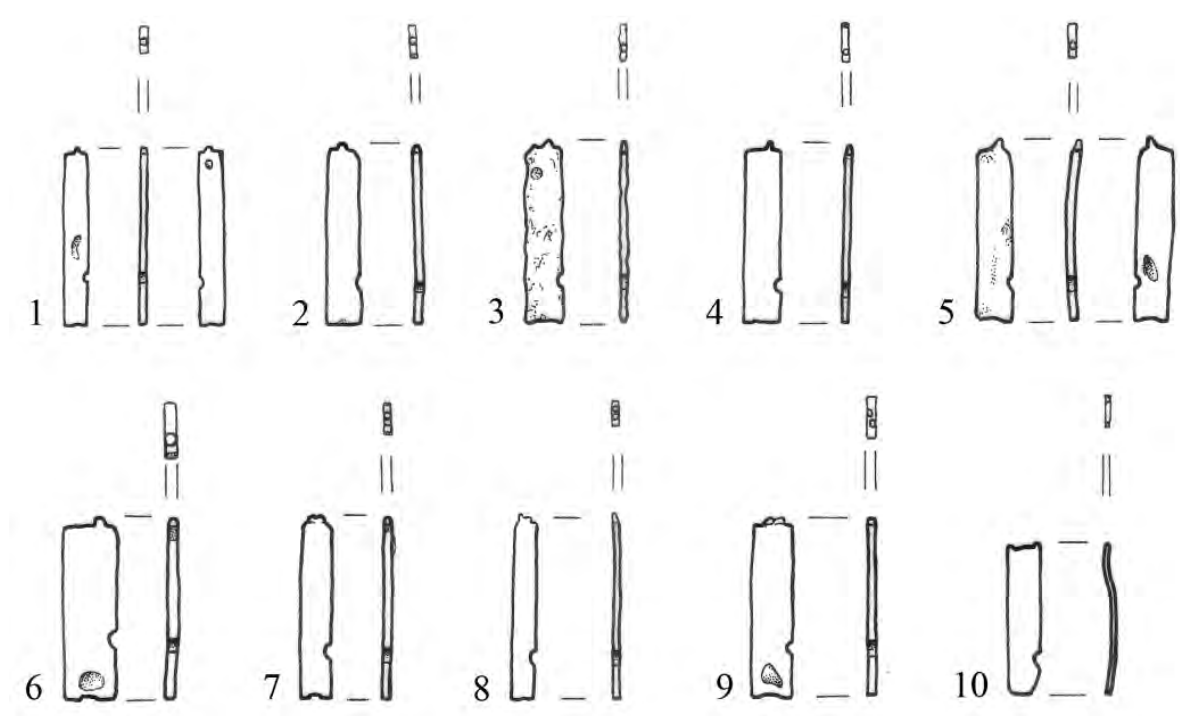

4
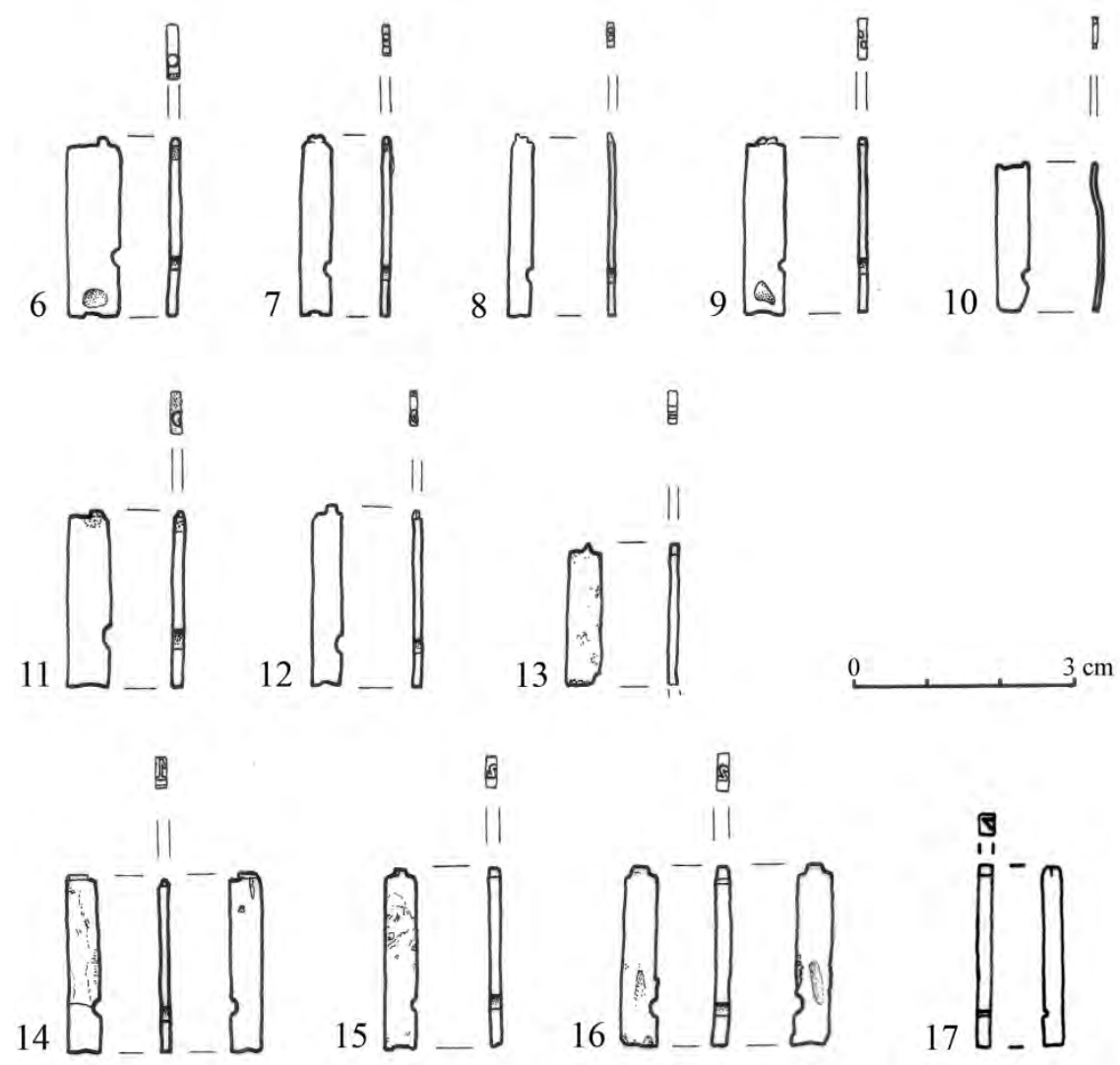

Ryc. 5. Czcionki ze znakami interpunkcyjnymi: 1-13 i cyframi: 14-17

Fig. 5. Punctuation marks: $1-13$ and numerals: $14-17$

starodrukach często ozdobniki powielano wielokrotnie w rzędzie lub w obramowaniu. Z pewnością na stanie Drukarni Akademickiej ozdobniki nie były w wersji pojedynczych egzemplarzy, ale te pochodzące $\mathrm{z}$ badań wykopaliskowych nie powtarzają się.

$\mathrm{W}$ omawianym zbiorze odnotowano przede wszystkim czcionki z motywami roślinnymi: były to różne liście, podwojona palmeta, kwiatek (ryc. 6). W wykazach 
wyposażenia drukarni przeczytać można o sumach przeznaczonych na odlanie „kwiatków”, „kwiatkow”, czy „kwitow” oraz finalików, czyli ozdobnych winiet (Sójka, 1977a, s. 26-28). Rozpoczęta kwerenda publikacji Drukarni Akademickiej w Poznaniu $^{6}$ dała interesujące wyniki odnośnie do użytkowania określonych czcionek-ozdobników (tab. 2). Stwierdzono, że najczęściej stosowano poziome listki z dwiema łodyżkami (ryc. 6:2). Dotychczas zarejestrowano je w 13 publikacjach. Również naj-

Tabela 2. Zestawienie ozdobników ze starodruków Drukarni Akademickiej odpowiadających czcionkom z Ostrowa Tumskiego na podstawie zbiorów Poznańskiego Towarzystwa Przyjaciół Nauk

Table 2. Decorative pieces from the old prints from the Academic Printing House corresponding to the ones from Ostrów Tumski based on the collections of PTPN

\begin{tabular}{|c|c|c|c|c|}
\hline Opis czcionki & Rycina & Autor i tytuł starodruku Drukarni Akademickiej & $\begin{array}{c}\text { Data } \\
\text { wydania }\end{array}$ & \begin{tabular}{|c}
$\mathrm{Nr}$ \\
w wykazie*
\end{tabular} \\
\hline $\begin{array}{l}\text { Liść poziomy } \\
\text { z dwoma } \\
\text { ogonkami } \\
\text { (ryc. 6:2) }\end{array}$ & $\begin{array}{l}\text { ryc. } 7: 3,4 \\
\text { ryc. } 7: 1,5 \\
\text { ryc. } 7: 2\end{array}$ & $\begin{array}{l}\text { Parnassus Musis... } \\
\text { Rosetum Rozdrazevianum... } \\
\text { Andrzej Margowski, Capitolium... } \\
\text { Filip Neriusz, św., Salutaria... } \\
\text { Mikołaj Zalaszowski, Ius Regni Poloniae... } \\
\text { Malachiasz Kramski, Kwiatki zebrane niebu... } \\
\text { Franciszek Powsiński, Drogi depozyt Ciała... } \\
\text { Tomasz Muszyński, Los fortuny.... } \\
\text { Maurycy Kiełkowski, Stawa stugi Bożej Jolenty... } \\
\text { Józef Declos, Ara amoris Divini... } \\
\text { Kazimierz Jarmundowicz, Navalis corona... } \\
\text { Hieronim Leyva, Examen episcoporum... } \\
\text { Ludwik Dziębiński, Elekcya w Polsce... }\end{array}$ & $\begin{array}{l}1690 \\
1691 \\
1692 \\
1698 \\
1699 \\
1714 \\
1722 \\
1722 \\
1723 \\
1728 \\
1729 \\
1735 \\
1738\end{array}$ & $\begin{array}{r}9 \\
14 \\
20 \\
59 \\
69 \\
113 \\
157 \\
154 \\
163 \\
196 \\
206 \\
243 \\
267\end{array}$ \\
\hline $\begin{array}{l}\text { Palmeta } \\
\text { pozioma } \\
\text { (ryc. 6:3) }\end{array}$ & $\begin{array}{l}\text { ryc. } 8: 2 \\
\text { ryc. } 8: 4 \\
\text { ryc. } 8: 3 \\
\text { ryc. } 8: 1\end{array}$ & $\begin{array}{l}\text { Parnassus Musis... } \\
\text { Rosetum Rozdrazevianum... } \\
\text { Andrzej Margowski, Capitolium... } \\
\text { Malachiasz Kramski, Kwiatki zebrane niebu... } \\
\text { Antoni Bliźniewski, Strzała wybrana... } \\
\text { Maurycy Kiełkowski, Stawa stugi Bożej Jolenty... }\end{array}$ & $\begin{array}{l}1690 \\
1691 \\
1692 \\
1714 \\
1715 \\
1723\end{array}$ & $\begin{array}{r}9 \\
14 \\
20 \\
113 \\
122 \\
163 \\
\end{array}$ \\
\hline $\begin{array}{l}\text { Strzelec } \\
\text { (ryc. 6:7) }\end{array}$ & ryc. 9:1 & $\begin{array}{l}\text { Andrzej Lipniewicz, Kalendarz polski y ryski [...] } \\
\text { na rok [...] } 1746 \ldots \\
\text { Andrzej Lipniewicz, Kalendarz, w którym }[\ldots] \text { na } \\
\text { rok }[\ldots] 1747 \ldots \\
\text { Franciszek Matawowski, Kalendarz polski y ruski } \\
\text { [...] na rok }[\ldots] 1772 . . . \\
\text { Polski i ruski świąt rocznych kalendarz [...] na rok } \\
{[\ldots] 1778 \ldots}\end{array}$ & $\begin{array}{l}1745 \\
1746 \\
1771 ? \\
1778\end{array}$ & $\begin{array}{r}313 \\
333 \\
538 \\
575\end{array}$ \\
\hline $\begin{array}{l}\text { Pastorał } \\
\text { (ryc. 6:1) }\end{array}$ & ryc. 10 & Marceli Dziewulski, Patron [...] zgody... & 1735 & 249 \\
\hline
\end{tabular}

* Karkucińska 1999 (tam dane bibliograficzne).

${ }^{6}$ Do tej pory udało się przeglądnąć 89 publikacji Drukarni Akademickiej ze zbiorów Poznańskiego Towarzystwa Przyjaciół Nauk (tj. ok. 15,4\% zachowanych 579 tytułów). Są to wydawnictwa z okresu od 1680 do 1779 r. Kwerenda w miarę możliwości będzie kontynuowana. 

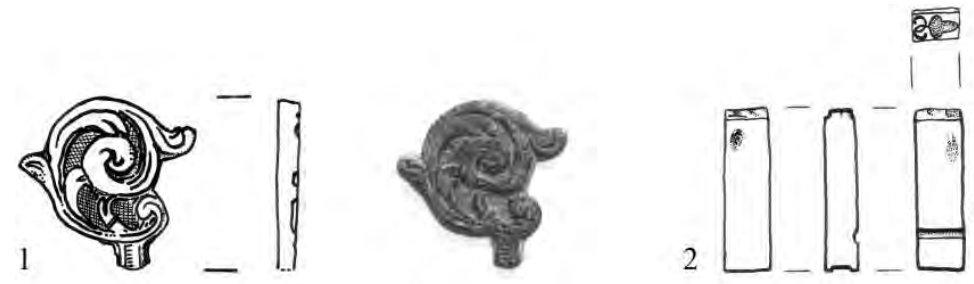
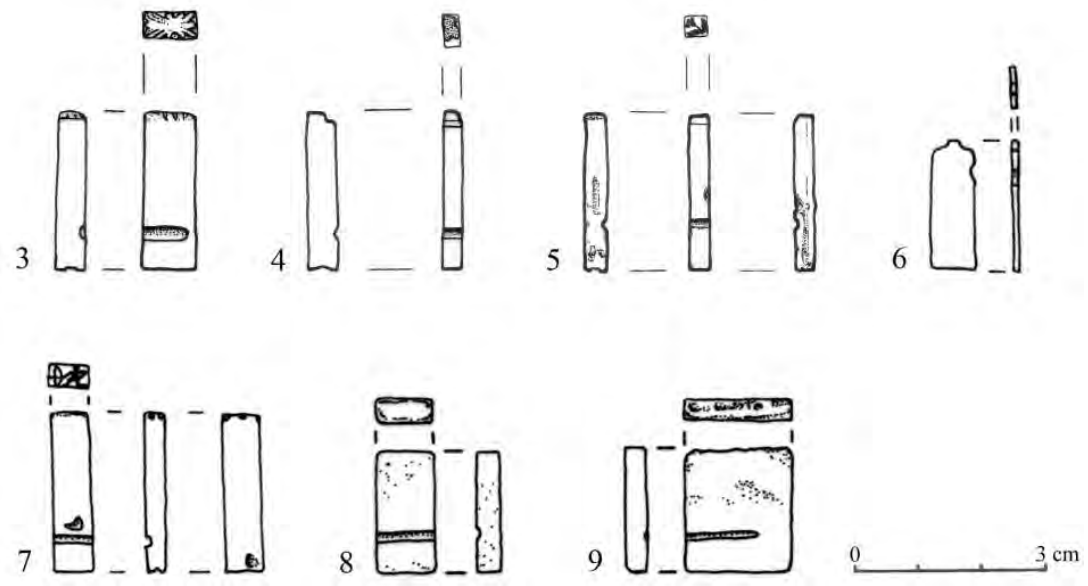

Ryc. 6. Czcionki - ozdobniki: 2-9 i matryca specjalna: 1

Fig. 6. Ornaments: $2-9$ and a special matrix: 1

dłużej były one użytkowane: od publikacji z 1680 (zapewne od początku funkcjonowania Drukarni Akademickiej) do 1738 r. (ryc. 7). Powielano je w dekoracyjne rzędy, ozdobne ramki, dekoracje góry bądź dołu strony. Często łączono z innymi ozdobnikami. Ich układ był bardzo różny: pionowy, łodyżkami do dołu lub do góry, oraz poziomy - łodyżkami zwróconymi w prawo bądź w lewo. Pozyskana podczas badań archeologicznych czcionka $\mathrm{z}$ takim liściem jest $\mathrm{w}$ bardzo dobrym stanie i była raczej krótko używana (wcale?). Wskazują na to wyraźne krawędzie główki, bez śladów starcia. Listki o podobnym kształcie, lecz nieco innych łodyżkach, znane są już z publikacji starszej drukarni Worlabów, np. z książki wydanej w 1610 r. autorstwa Pawła Szczerbica Ius Municipale (Topolski 1988, ryc. 70). Łodyżki o jeszcze bardziej wyrafinowanym zakończeniu miały podobnego kształtu ozdobniki - np. liście z drukarni krakowskich (Sowiński 1988, ryc. 22). Była to zatem czcionka dość modna, ewoluująca w XVII w. i w pierwszej połowie XVIII w., przy czym zmiany graficzne w matrycy odnotowywane są przede wszystkim w ukształtowaniu łodyżki. W podobnym okresie co czcionkę z dwoma łodyżkami używano również poziomego ozdobnika z wyobrażeniem roślinnym ,palmety” (ryc. 6:3). Określono takie czcionki w 6 publi- 


\section{0 s. 509 TITVLVS DECIMVS SEPTIMVS}

\section{2}

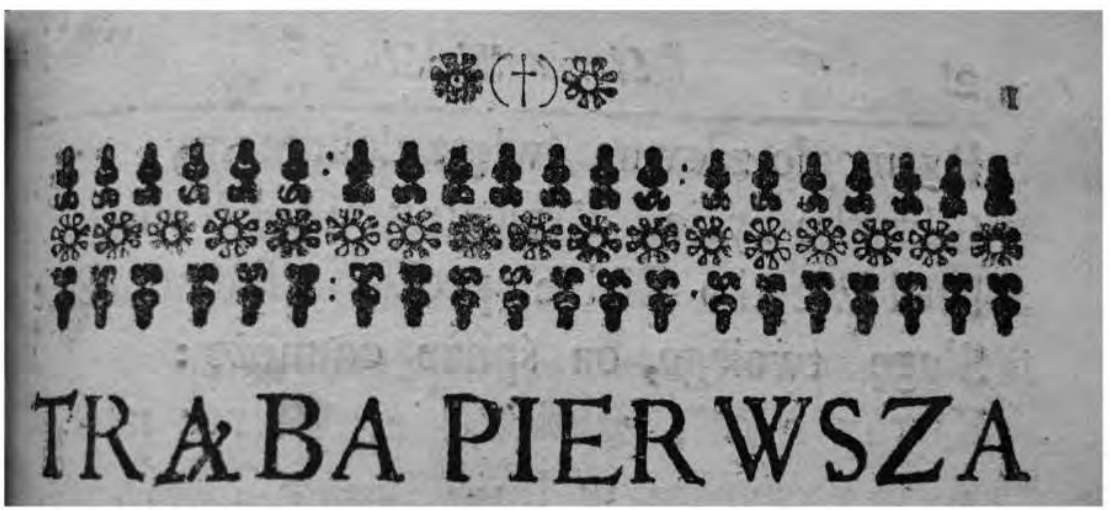

3

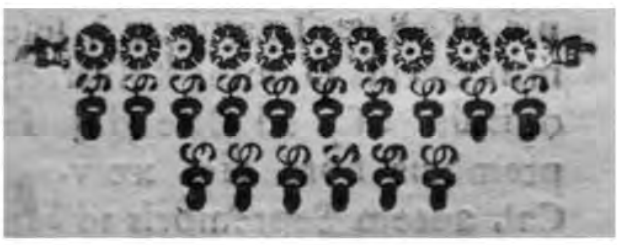

4
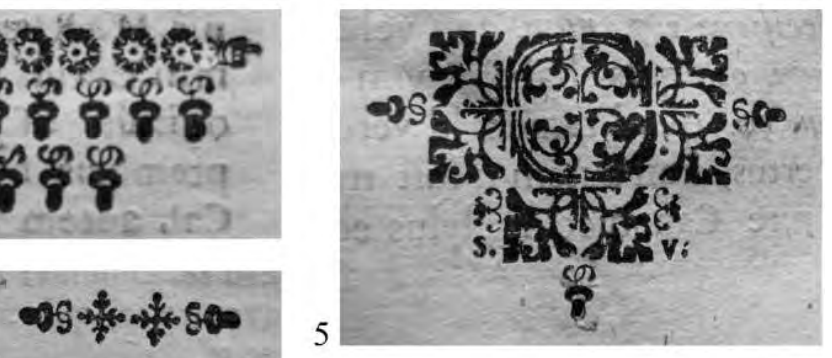

Ryc. 7. Przykłady publikacji, w których użyto czcionek z liściem z dwoma łodyżkami: 1, 5 - Zalaszowski, Ius Regni Poloniae... (1699 r.); 2 - Kiełkowski, Stawa stugi Bożej Jolenty... (1723 r.); 3, 4 - Filip Neriusz, św., Salutaria... (1698 r.). Zbiory Poznańskiego Towarzystwa Przyjaciół Nauk (dalej: PTPN )

Fig. 7. Examples of publications in which pieces ornamented with a two-stem leaf were used: $1,5-\mathrm{Za}$ laszowski, Ius Regni Poloniae... (1699); 2 - Kiełkowski, Stawa stugi Bożej Jolenty... (1723); 3, 4 - Filip

Neriusz, św., Salutaria... (1698). Collection of Poznańskie Towarzystwo Przyjaciół Nauk (PTPN)

kacjach wydanych w latach 1680-1723 - z wyjątkiem jednej są to te same pozycje wydawnicze, w których pojawia się czcionka z liściem z dwoma łodyżkami. Czcionka z ,palmetą" nosi ślady długiej i intensywnej eksploatacji, co odzwierciedla się w silnie wytartym oczku. W drukach pojawiają także się niedokładnie odciśnięte lub zalane ozdobniki, które niewątpliwie były wykonywane mocno zużytymi stemplami (ryc. 8). Na jednym egzemplarzu widnieje postać łucznika (ryc. 6:7). Jest on ustawiony bokiem, klęczy na jednym kolanie, z drugą nogą wysuniętą do przodu. Łuk ze strzałą trzyma jedną ręką, drugą ma odchyloną do tyłu. Na słupku czcionki 
czytelne są ślady czerwonej farby lub korozji ${ }^{7}$. Wykorzystanie takich czcionek potwierdzono w kalendarzach drukowanych w Drukarni Akademickiej w latach 17451778 (ryc. 9). Czcionka ta stanowiła symbol znaku zodiaku - Strzelca. Kalendarze wydawane w Drukarni Akademickiej z tego okresu oprócz pełnienia swej podstawowej funkcji były również poradnikami dotyczącymi prac gospodarskich: siania, przycinania roślin, zbioru plonów, hodowli zwierząt; zabiegów medycznych: instruowały o odpowiednim czasie na stawianie baniek lub puszczanie krwi itp. Obok zodiakalnych symboli - piktogramów - również używano w kalendarzach symboli greckich, a także symboli astronomicznych (faz księżyca, planet, Słońca) oraz symboli dla omawianych porad gospodarskich lub medycznych. W kalendarzach znaki zodiaku odciskano za pomocą czarnej farby. Jednak często stosowano wyróżnienia innych symboli - instrukcji, które drukowane były farbą czerwoną. Być może od sąsiadującej ze Strzelcem czcionki pochodzi wzmiankowany powyżej czerwony ślad na słupku. Prawdopodobnie do drukowania kalendarzy wykorzystywano również mocno startą i skorodowaną czcionkę (ryc. 6:4). Kształt oczka przypomina symbol stawiania baniek i pijawek lub siania. Podobne przeznaczenie mogła mieć również

1

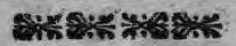
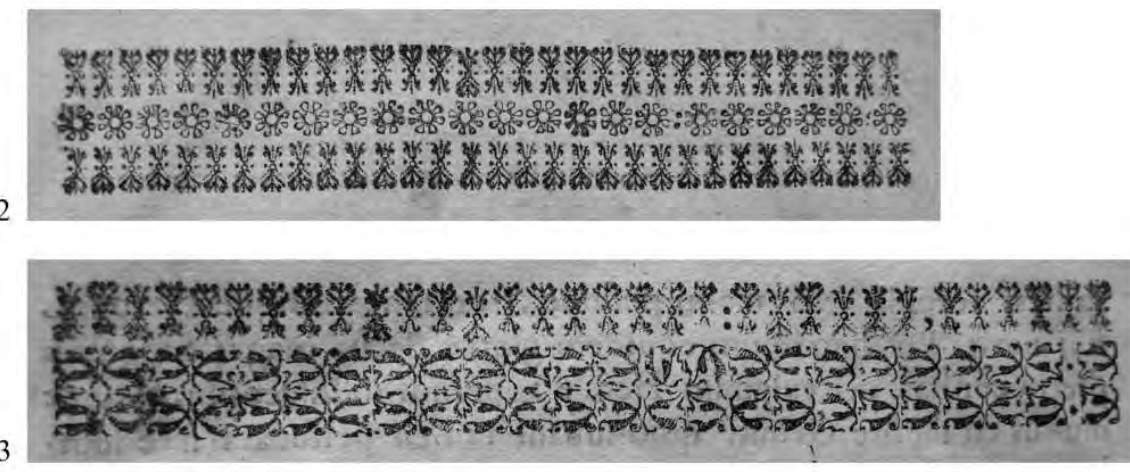

3

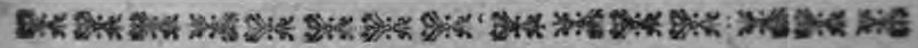

POSNANIA

4

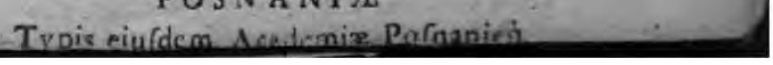

Ryc. 8. Przykłady publikacji, w których użyto czcionek z „palmetą”: 1 - Kramski, Kwiatki zebrane niebu... (1714 r.); 2 - Parnassus Musis... (1690 r.); 3 - Margowski, Capitolium... (1692 r.); 4 - Rosetum Rozdrazevianum... (1691 r.). Zbiory PTPN

Fig. 8. Examples of publications in which "palmette" type was used: 1 - Kramski, Kwiatki zebrane niebu... (1714); 2 - Parnassus Musis... (1690); 3 - Margowski, Capitolium... (1692); 4 - Rosetum Rozdrazevianum... (1691). Collection of PTPN

\footnotetext{
${ }^{7}$ Konieczność przeprowadzenia analiz specjalistycznych.
} 

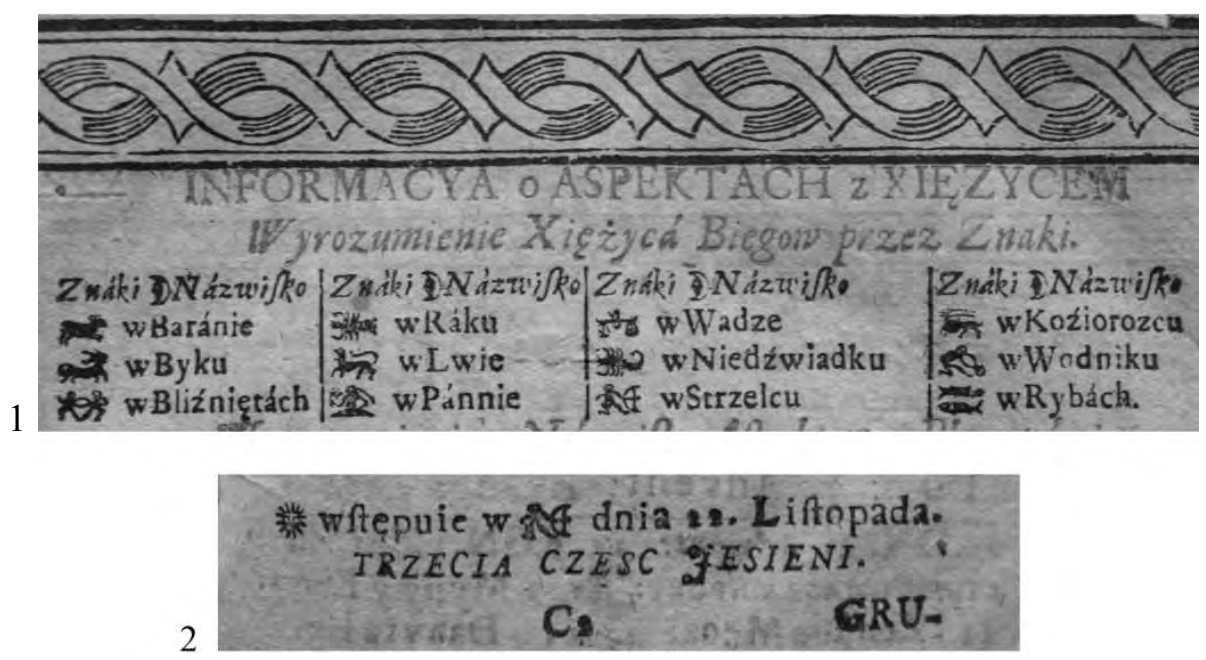

Ryc. 9. Przykłady publikacji kalendarzy, w których użyto czcionek ze Strzelcem: 1 - Lipniewicz, Kalendarz polski y ruski [...] na rok [...] 1746... (1745); 2 - Polski i ruski świąt rocznych kalendarz [...] na rok [...] 1778... (Zbiory PTPN)

Fig. 9. Examples of calendars in which pieces with Sagittarius were used: 1 - Lipniewicz, Kalendarz polski y ruski [...] na rok [...] 1746... (1745); 2 - Polski i ruski świat rocznych kalendarz [...] na rok [...] 1778... (Collection of PTPN)

czcionka z oczkiem o kształcie kwiatu z dwoma listkami i z łodyżką (ryc. 6:5). Dotychczas nie znaleziono jej drukowanego odpowiednika. Dwie, dość zniszczone na główkach czcionki mają prawdopodobnie arabeskowe ramki (ryc. 6:8, 9). Jednak są one na tyle silnie wyeksploatowane, że trudno określić ich pierwotny rysunek. Jedna czcionka nosi ślady naprawiania i wtórnego wykonania matrycy drukarskiej od strony dolnej płaszczyzny (odwrócona została do góry nogami). Wtórnie nadano jej kształt owalu (ryc. 6:6).

Szczególną estetyką wykonania odznacza się płaska, również ołowiana czcionka/matryca (ryc. 6:1). Jej wysokość wynosi 4/3,5 mm, prawdopodobnie doczepiana była do drewnianego klocka. Przedstawia ona górny fragment pastorału biskupiego - jego pióro o dekoracyjnym zakończeniu w kształcie liści akantu. Na wklęsłych płaszczyznach matrycy widoczne są pozostałości czarnej farby ${ }^{8}$. Zastosowanie takiej matrycy zostało poświadczone jednorazowo w publikacji z 1735 r. Jest to druk kazania wygłoszonego przez franciszkanina, ks. Marcelego Dziewulskiego, w kościele Norbertanów w Strzelnie 2 lipca 1734 r. Wówczas prepozytem generalnym w Polsce był Mikołaj Ignacy Łukowski - infułat strzeleński (niekiedy nazwisko pisane Łukoski, tj. we wspomnianym druku) - i to jemu dedykowane jest kazanie. Odciśniętą matrycę $\mathrm{z}$ pastorałem odnajdujemy na odwrocie strony tytułowej jako dopełnienie szerszej

\footnotetext{
${ }^{8}$ Konieczność wykonania analiz specjalistycznych.
} 
kompozycji. Grafika wykonana prawie na całą stronę publikacji wyobraża tarczę herbową z koroną szlachecką, a na niej godło Szeliga (ryc. 10). Na herbie przedstawiono na dole tarczy półksiężyc $\mathrm{z}$ rogami zwróconymi ku górze i dochodzący do niego, znajdujący się pośrodku tarczy - krzyż łaciński. Powyżej zamiast klejnotu widnieje kapelusz biskupi ze sznurem $\mathrm{z}$ chwostami. Po lewej stronie u góry odbito za pomocą oddzielnej matrycy pastorał. Po prawej - zapewne także dostawioną samodzielną matrycą - odciśnięto mitrę biskupią. W zestawieniu herbów przy nazwisku Łukoski występują tylko herby Dołęga i Łukos. Natomiast nazwisko Łukowski oraz Łukocki łączy się m.in. z herbem Szeliga (Gajl 2003, s. 227, 291). I niewątpliwie wśród rodów herbu Szeliga należałoby szukać przodków infułata ze Strzelna. Przywilej noszenia szat i insygniów biskupich otrzymał M.I. Łukowski od papieża Benedykta XIII w dniu 7 listopada 1729 r. Od tego czasu aż do sekularyzacji klasztoru tytuł prepozyta-infułata przechodził na jego następców (Kabaciński 2001, s. 61, 134).

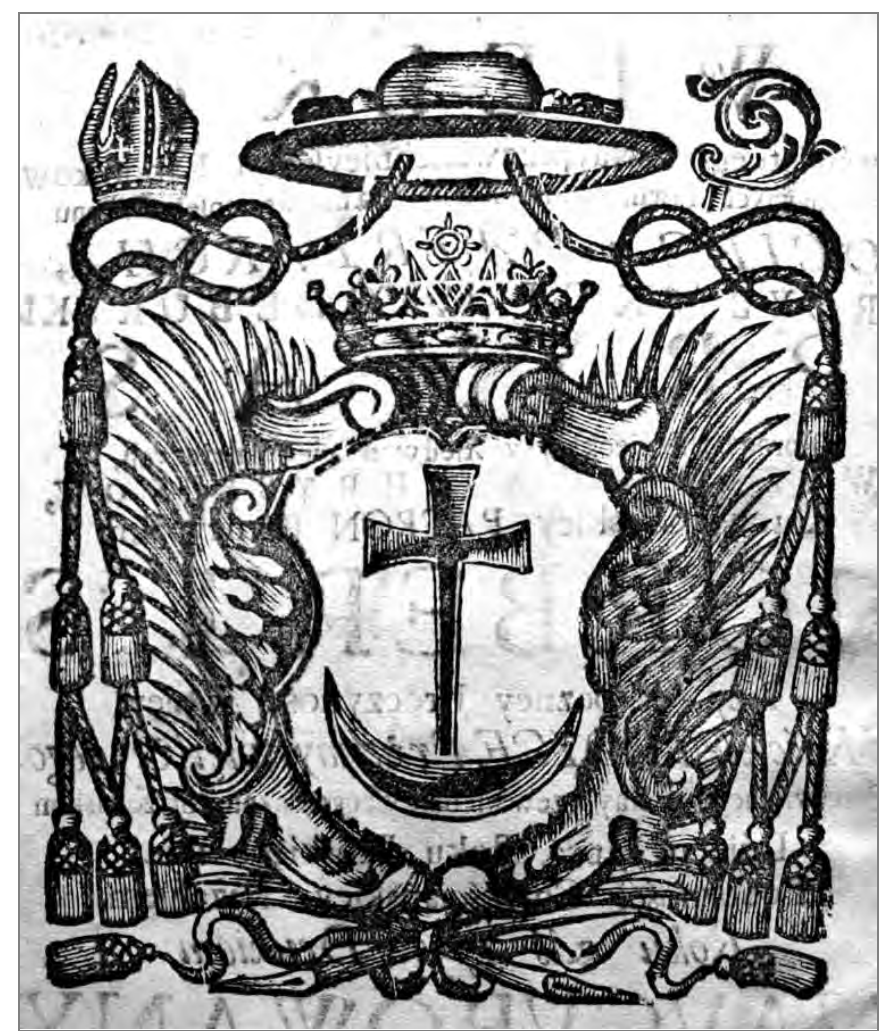

Ryc. 10. Strona z publikacji z wykorzystaniem matrycy pastorału z publikacji kazania Marcelego Dziewulskiego Patron [...] zgody ... (1735). Zbiory PTPN

Fig. 10. A page from the publication of Marceli Dziewulski's sermon in which a crosier ornament was used, Patron [...] zgody ... (1735). Collection of PTPN 


\section{Czcionki puste}

To czcionki o słupku zakończonym płasko, bez oczka (ryc. 11), tworzą liczną grupę w omawianym zbiorze (21 egz. - 23,1\%). Tzw. ślepy materiał zecerski wykorzystywany był jako justunek. W kasztach zecerskich wypełniano nimi puste przestrzenie wokół czcionek ze znakami, aby całość tworzyła jednolity blok. Do takiego uzupełniania stosowano rozmaite kostki, sztabki, blaszki, którymi regulowano odstępy między wierszami i słowami. Biorąc pod uwagę to, że w omawianym zbiorze
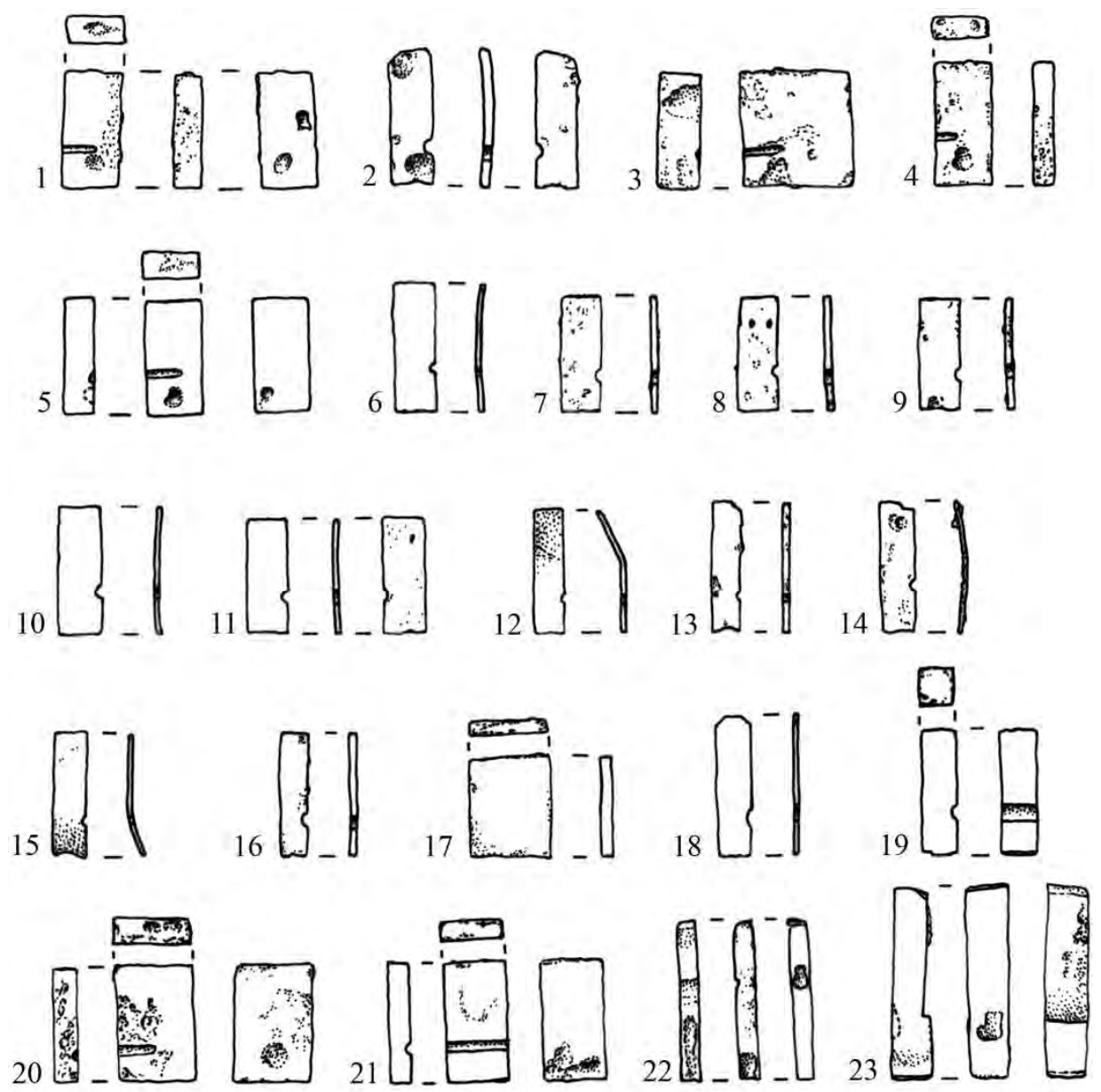

Ryc. 11. Ślepy materiał zecerski

Fig. 11. Spaces 


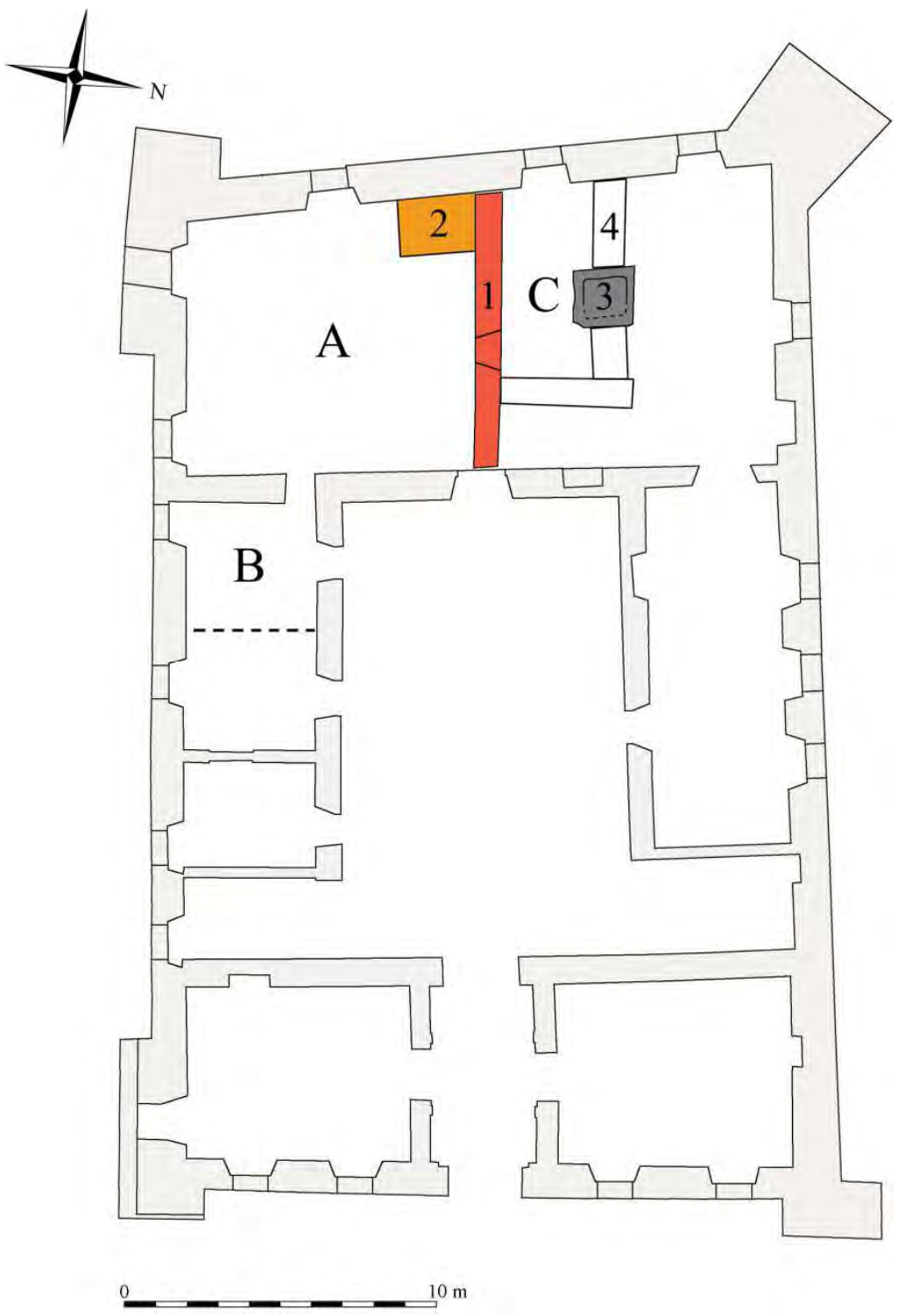

Ryc. 12. Lokalizacja Drukarni Akademickiej (A) i domniemana lokalizacja magazynu drukarni (B); na planie budynku zaznaczono fundamenty i ściany odsłonięte podczas badań archeologiczno-architektonicznych: 1 - XVI-wieczna ściana działowa (z zaznaczonym przejściem na podstawie rysunku L. Frankiewicza z 1898 r.); 2 - fundament pieca; 3 - fundament wielkiego komina; 4 - fundamenty ścian barokowych; $\mathrm{C}$ - kuchnia

Fig. 12. Location of the Academic Printing House (A) and the supposed location of its storehouse (B) - within the outline of a building foundations and walls unearthed during the archaeological and architectural investigations have been marked: 1 - the sixteenth-century partition wall (with a gateway, based on the drawing by L. Frankiewicz, 1898); 2 - the foundation of the furnace; 3 - the foundation of the great chimney; 4 - foundations of the Baroque walls; $\mathrm{C}$ - kitchen 
9 czcionek jest dodatkowo znakowanych: podciętymi krawędziami i/lub żłobieniami powierzchni, można domyślać się, iż były one pierwotnie materiałem typograficznym służącym do druku. Po wyeksploatowaniu - całkowitym starciu powierzchni ewentualnego znaku - mogły być dalej wykorzystywane w kasztach jako justunek. Takie wyraźne przetarcia, korozje, „znaki” są widoczne na pięciu czcionkach. Prawdopodobnie jako puste czcionki używane były dwie kolejne wykonane $\mathrm{z}$ innego materiału niż ołów, zapewne z mosiądzu. Te właśnie mają inaczej wykonaną sygnaturę, tzn. od góry ukośnie podciętą, a od dołu prostą (ryc. 11:22, 23). Są one przy tym trochę dłuższe niż tradycyjne ołowiane słupki, jedna z nich osiąga wysokość aż 31,4 mm. J. Sowiński pisze, że z mosiądzu rytowane były zapewne patryce - wzorniki do odciśnięcia matryc służących do odlewania czcionek (Sowiński 1988, s. 225-226, ryc. 12). Również 4 czcionki ołowiane mają częściową sygnaturę (tylko przy lewym boku, ryc. 11:1, 3-5, 20), a jeden z ołowianych sześcianów nie ma jej wcale (ryc. 11:17).

\section{Czcionki nieokreślone i uszkodzone}

16 czcionek $(17,6 \%)$ to przedmioty uszkodzone w górnej części słupka lub skorodowane, dlatego nie można stwierdzić, czy miały jakiś znak, czy też były „ślepym" materiałem zecerskim. Wszystkie mają sygnaturę (jedna z częściową sygnaturą), a na 5 egzemplarzach stwierdzono znakowanie w postaci otworów na bocznych powierzchniach i/lub podciętej górnej krawędzi. Może to oznaczać, że nie był to tylko justunek, że czcionki pierwotnie posiadały znak na główce.

Źródła historyczne (przede wszystkim rachunki za zakup bądź naprawy oraz inwentarze) wymieniają poza czcionkami wiele innych przedmiotów i narzędzi, które były na wyposażeniu drukarni w gmachu Akademii. Drukarnia dysponowała prasami: drukarską i miedziorytniczą, ramami do pras, kasztami zecerskimi, formami do składania tekstów, kociołkiem miedzianym do ługu, bańką glinianą do oleju, bańką miedzianą do pokostu, kałamarzami i łopatką do farb, kapami płóciennymi oraz kamieniem z kurantem do robienia rubrum (Sójka 1977a, s. 25-28). Jednak wymienione ,sprzęty” drukarskie i urządzenia nie znajdują potwierdzenia w pozyskanym dotychczas materiale archeologicznym.

\section{PRODUKCJA CZCIONEK}

W źródłach pisanych odnoszących się do drukarni z terenu Ostrowa Tumskiego nie ma wzmianki o giserni - miejscu wytwarzania materiałów typograficznych. Wiadomo natomiast, że gisernia wraz z introligatornią istniała w tym samym czasie co Drukarnia Akademicka na terenie lewobrzeżnego Poznania przy drukarni jezuickiej (Sójka 1977b, s. 112). Drukarnia Akademicka, która przejęła urządzenia i zapewne materiał typograficzny po ks. Laktańskim, w ciągu swego prawie stuletniego funkcjonowania musiała go wielokrotnie uzupełniać. Czcionki sprowadzano więc 
z odległych giserni z miast niemieckich, tzn. z Wrocławia i z Frankfurtu nad Odrą, co potwierdzają liczne rachunki (Sójka 1977a, s. 25) ${ }^{9}$. Dziwić może jednak brak potwierdzonej współpracy z poznańskimi jezuitami. Czyżby w grę wchodziła obawa przed konkurencją? Nie wiadomo również, czy na jakimś etapie funkcjonowania drukarnia nie zaczęła sama odlewać czcionek na własne potrzeby. Podczas badań wokół budynku i we wnętrzu Akademii natrafiono na liczne wytopki i bryłki ołowiowe - choć mogą być one związane także ze stacjonującymi tutaj w $1711 \mathrm{r}$. wojskami moskiewskimi czy późniejszymi koszarami pruskimi (od drugiej połowy XIX w.). Obok bryłek ołowiu zarejestrowano na stanowisku liczne kulki ołowiane do broni palnej (po ich odlewie nad ogniem zostawało wiele niekształtnych bryłek i placków ołowiu). Niewątpliwie również podczas przetapiania ołowiu na kule mogła ulec zniszczeniu część materiału typograficznego. W czasie zamiany budynku na koszary i magazyny wojsk moskiewskich źródła odnotowują bowiem olbrzymie zniszczenia w jego wnętrzach i wyposażeniu (Linette 1999, s. 184-185), co nie ominęło pewnie i drukarni.

\section{LOKALIZACJA DRUKARNI NA OSTROWIE TUMSKIM}

Pierwsza drukarnia na terenie Ostrowa Tumskiego, która jednocześnie była drugą po założonej przez M. Nehringa (1577-1578) drukarnią działającą w Poznaniu, lokalizację znalazła w dawnej szkole katedralnej przy styku obecnych ulic Dziekańskiej i ks. I. Posadzego (Nowacki 1964, s. 677). W 1684 r. przejął i wyremontował zrujnowany budynek szkolny drukarz, Jan Wolrab. Po jego śmierci († 1590) drukarnię prowadziła wdowa, Barbara ( $\dagger$ 1598), a po niej synowie: Marcin i Jan. W tym miejscu działała zapewne do 1610 r., a więc łącznie około 26 lat. Później została przeniesiona w nieznane miejsce do Poznania lewobrzeżnego (Sójka 1977e, s. 286).

Śladowe przesłanki pozwalają na postawienie hipotezy o ciągłości korzystania ze sprzętów po drukarni Wolrabów, poprzez drukarnię Wojciecha Regulusa i jego spadkobierców, aż po Drukarnię Akademicką. Istnieje zbieżność dat końca działalność i drukarni Wolrabów i początków pracy drukarni Regulusa na Chwaliszewie w $1636 \mathrm{r}$. (Łabędzka-Topolska 1988, s. 537; Sójka, 1977d, s. 210-211). J. Orańska dostrzegła również identyczne z wolrabowskimi inicjały w drukach Regulusa (Orańska 1956, s. 163-164). Także J. Sójka pisze o powtarzalności zasobów typograficznych, zdobniczych i ilustracyjnych, używanych wcześniej przez Wolrabów, w drukach W. Regulusa i jego następców (Sójka 1977d, s. 211). W 1679 r. drukarnia po następcach W. Regulusa zostaje sprzedana ks. Wojciechowi Laktańskiemu (Sójka 1977c, s. 174).

W 1689 r. wyposażenie drukarni przejęte po ks. Laktańskim trafiło do gmachu Akademii. Źródła nie informują, w którym pomieszczeniu urządzono wówczas ofi-

\footnotetext{
${ }^{9}$ Konieczne wydaje się wykonanie analiz specjalistycznych metali, ponieważ czcionki już na podstawie cech wyglądu różnią się jakością użytego ołowiu, co być może odpowiada przynajmniej dwóm różnym giserniom.
} 
cynę wydawniczą (Nowacki 1964, s. 693; Sójka 1977a). Przypuszczalnie znajdowała się ona w jednej z sal na parterze budynku - rejestrowane archeologicznie pozostałości materiału typograficznego koncentrują się szczególnie po północnej ( 27 czcionek) i zachodniej (48 czcionek) stronie Akademii. Tu należałoby się doszukiwać pierwotnej lokalizacji drukarni. Dopiero inwentaryzacja pomieszczeń przeprowadzona w 1781 r., a więc już po likwidacji drukarni, wskazuje pomieszczenia po dawnej oficynie na parterze w narożu południowo-zachodnim skrzydła zachodniego, obok pomieszczeń kuchennych (Linette 1999, s. 206). W opisie tym czytamy:

Pod tym na dole kominem jest ognisko do gotowania obszerne, pod ogniskiem, czyli klepiskiem, piec do chleba i w tenże wielki komin wchodzą czeluście pieca drukarnianego, która jest na tymże piontrze dolnym dość obszerna [f. 27] w rogu zachodniopołudniowym, której stan jest takowy: Izba ta duża jest, drzwi do niej stare, drewniane, na zawiasach żelaznych z zamkiem nadpsutym. Okien ma trzy w ramach drewnianych starych, jakoż cokolwiek okowane. Szyby oprawne w ołów po większej części popękane, w jednym zaś oknie cała kwatera wybita. Piec [z] kachli zielonych niewielkich. Podłoga tarcicowa sosnowa, dawna, miejscami zła. Posowa także z tarcic stara na balkach podciągiem wspartych. Drukarskie rzeczy znajdują się w tej izbie. Pisma i inne sprzęty te następują $[\ldots]$.

Wówczas (tj. w drugiej połowie XVIII w.) skrzydło północne na parterze zajmowały sale do nauki poetyki i retoryki oraz w pobliżu kuchni lokowane były dwie ciemne komory. Tak więc prace związane z przygotowaniem kaszt i drukowaniem odbywały się w zachodniej części gmachu. W 2006 r. podczas badań archeologiczno-architektonicznych związanych z generalnym remontem i adaptacją pomieszczeń na potrzeby Muzeum Archidiecezjalnego dość dobrze rozpoznano skrzydło zachodnie budynku dawnego kolegium (Kóčka-Krenz 2007; Skuratowicz 2007). Pod posadzką natrafiono na pomieszczenia kuchenno-gospodarcze mieszczące się w jego części środkowej i północnej wraz z fundamentami pieców i podmurówką wielkiego komina. Część północną (kuchenną) od południowej (izby drukarskiej) oddzielała murowana ściana działowa o szerokości $0,75 \mathrm{~m}$. Relikty jej odsłonięto na całej linii w poprzek skrzydła zachodniego (ryc. 12:1). Pomimo braku przewiązania ściany działowej ze ścianą zachodnią (stanowiącą nieco starsze umocnienia obronne) i wschodnią (okalająca dziedziniec) stwierdzić można, że podział ten nastąpił już na etapie budowy gmachu Akademii w XVI w. Przemawia za tym technika wykonania i wielkość cegieł. Ściana została wymurowana z cegieł ,palcówek” o średnich wymiarach $28,2 \times 14 \times 8,4 \mathrm{~cm}$ w wątku gotyckim (pierwszy dolny rząd wymurowano „na rolkę"). Fugi starannie zagładzono. Mur ceglany pełen został posadowiony na fundamencie $\mathrm{z}$ kamieni polnych nieobrobionych, zalanych warstwami zaprawy wapiennej z gruzem ceglanym. Z planu przyziemia Akademii, wykonanego ok. $1898 \mathrm{r}$. przez Leona Frankiewicza, wynika, że istniało przejście z rozglifieniem w stronę północną, bezpośrednio łączące kuchnię i drukarnię (Skuratowicz 2007, s. 58). Dzięki 
odsłonięciu ściany działowej można przeliczyć, że powierzchnia izby Drukarni Akademickiej wynosiła ok. $78 \mathrm{~m}^{2}$.

W narożniku północno-zachodnim pomieszczenia drukarskiego, tuż przy ścianie, na prawo od wspomnianych drzwi z kuchni, natrafiono na fundament dużego pieca (ryc. 12:2). Jego wymiary wynoszą $2,6 \times 1,9 \mathrm{~m}$ (dłuższy bok biegnie wzdłuż ściany zachodniej). Wielkość cegły „palcówki” $(28,4 \times 14,3 \times 8,3 \mathrm{~cm})$ oraz sposób wymurowania wskazują, że fundament ten również powstał jeszcze w XVI w. Z badań archeologicznych prowadzonych w budynku i przy zachodnim skrzydle Akademii pozyskano liczny zbiór kafli piecowych, w tym często pojawiające się kafle z zielonym szkliwem. Jednak różnorodność motywów oraz fakt rejestrowania obok siebie zarówno kafli renesansowych, jak i barokowych nie pozwala niestety na przeprowadzenie rekonstrukcji pieca stojącego na odkrytym fundamencie. Zapewne urządzenie to oprócz funkcji grzewczych od schyłku XVII w. i przez XVIII w. mogło być wykorzystywane również jako piec drukarniany. Przemawia za tym lokalizacja w bezpośrednim sąsiedztwie kuchni, gdzie natrafiono na potężny fundament komina, do którego miało być dociągnięte wyprowadzenie dymu od pieca drukarni. Wówczas obiekt ten obok właściwości dających ciepło mógł być miejscem służącym do pozyskiwania popiołu do produkcji farb czy też do smażenia pokostu. J. Sójka, z powodu braku źródeł pisanych, dopuszczał również w pierwszym okresie funkcjonowania drukarni możliwość sprowadzania popiołu, pokostu i barwników na potrzeby produkcji farb z zewnątrz (Sójka 1977a, s. 28). Informacje o smażeniu pokostu z oleju lnianego pochodzą dopiero z lat 1743-1746. Natomiast według źródeł pisanych piec do produkcji sadzy zaczęto stawiać w latach 1746-1749. Nie wiadomo, czy mowa tu o kolejnym piecu, czy też wykorzystano solidne podmurowania starszego urządzenia grzewczego.

Bezpośrednio z izby drukarni prowadziły drzwi do pomieszczenia służącego drukarzom za magazyn.

[f. 28] [...] Z tejże izby, czyli drukarni, są sosnowe dobre w ramach sosnowych z zamkiem prostym, ale nie złym, a to do komory, w której papiory drukowane składały się. W komorze tej jest okno jedno, w ramie $\mathrm{z}$ drewnianej szyb drobnych w ołów oprawnych, na którym okow stary, za oknem stara krata żelazna [z] drobnych prętów. Są też tu w tej komorze ławy, czyli stołki długie, police z tarcic prostych na składanie papierów. Posowa stara, drewniana. Posadzka z cegły (Linette 1999, s. 206).

Tak według opisu z 1781 r. miał wyglądać magazyn drukarni (Linette 1999, s. 206). Pomieszczenie to na planie L. Frankiewicza prawdopodobnie lokalizować można już w skrzydle południowym; zapewne to pierwsza niewielka izba na styku $\mathrm{z}$ drukarnią.

Po rozwiązaniu szkoły mieszczącej się w gmachu Akademii w 1780 r. drukarnia jeszcze do 1787 r. wydawała pod nazwą Drukarni Seminarium Diecezjalnego (Kuklińska 1988, s. 904; Sójka 1977a, s. 35). 


\section{PODSUMOWANIE}

Pozostałości po drukarni w postaci czcionek wymagają jeszcze dalszych studiów i badań specjalistycznych. Dzięki badaniom archeologiczno-architektonicznym w Akademii Lubrańskiego możliwe było rozpoznanie powierzchni pomieszczenia dawnej Drukarni Akademickiej, pozostałości pieca oraz pomieszczeń kuchennych wraz z podstawą wielkiego komina. Czcionki natomiast są śladem po narzędziach pracy drukarzy działających na poznańskim Ostrowie Tumskim. Być może niektóre pochodzą ze starszej drukarni Wolrabów z przełomu XVI i XVII w., choć koncentracja materiałów zecerskich w pobliżu Akademii pozwala większość z nich pewnie łączyć z już młodszą Drukarnią Akademicką. Obok zachowanych do dziś 579 tytułów publikacji (Karkucińska 1999), które przygotowano i wydrukowano w latach 1689-1786 pod szyldem Drukárni Akádemickiey, czcionki stanowią istotny materialny ślad pracy poznańskich drukarzy oraz kontaktów Poznania z miastami niemieckimi - Wrocławiem i Frankfurtem nad Odrą.

\section{BIBLIOGRAFIA}

Gaj1 T.

2003 Herby szlacheckie Rzeczpospolitej Obojga Narodów. Gdańsk: Wydawnictwo L\&L.

Kabaciński R.

2001 Historia miasta Strzelna (Przetom XIV/XV wieku - 1773 r.). Bydgoszcz: Akademia Bydgoska.

Karkucińska W.

1999 Katalog publikacji Drukarni Akademickiej w Poznaniu. W: Kronika Miasta Poznania, 2(1999), s. 252-298.

Kóčka-Krenz H.

2007 Odkrycia archeologiczne. W: J. Skuratowicz (red.), Akademia Lubrańskiego (s. 13-20). Poznań: Wydawnictwo Miejskie.

Kuklińska K.

1988 Czytelnictwo i drukarstwo, księgarstwo. W: J. Topolski (red.), Dzieje Poznania (t. 1, cz. 2, s. 899-908). Warszawa-Poznań: Państwowe Wydawnictwo Naukowe.

Linette R.

1999 Z dziejów budynku dawnej Akademii Lubrańskiego. W: Kronika Miasta Poznania, 2(1999), s. 181-213.

Łabędzka-Topolska M.D.

1988 Oficyny drukarskie i ich produkcja. W: J. Topolski (red.), Dzieje Poznania (t. 1, cz. 1, s. 533-538). Warszawa-Poznań: Państwowe Wydawnictwo Naukowe.

Nowacki J.

1964 Dzieje Archidiecezji Poznańskiej, t. 2, Archidiecezja poznańska w granicach historycznych i jej ustrój. Poznań: Księgarnia św. Wojciecha.

Orańska J.

1956 Grafika i rysunek do końca XIX w. W: K. Malinowski (red.), Dziesięć wieków Poznania (t. III, s. 157-192). Poznań-Warszawa: Wydawnictwo Sztuka. 
Sikora M.

2012 Wytwory metalowe ze stanowiska Posadzego 5. W: H. Kóčka-Krenz (red.), Poznań we wczesnym średniowieczu (t. VII, s. 203-214). Poznań: Wydawnictwo Poznańskie.

Skuratowicz J.

2007 Akademia Lubrańskiego. Poznań: Wydawnictwo Miejskie.

Sowiński J.

(1988) Polskie drukarstwo. Wrocław-Warszawa-Kraków-Gdańsk-Łódź: Zakład Narodowy im. Ossolińskich.

Sójka J.

1977a Akademicka Drukarnia Poznań 1689-1780. W: A. Kawecka-Gryczowa (red.), Drukarze dawnej Polski od XV do XVIII w. (t. 3, cz. 1, Wielkopolska, s. 17-35). WrocławWarszawa-Kraków-Gdańsk: Zakład Narodowy im. Ossolińskich.

Sójka J.

1977b Jezuici Poznań. W: A. Kawecka-Gryczowa (red.), Drukarze dawnej Polski od XV do XVIII w. (t. 3, cz. 1, Wielkopolska, s. 105-134). Wrocław-Warszawa-Kraków-Gdańsk: Zakład Narodowy im. Ossolińskich.

Sójka J.

1977c Młodujewicz Wojciech. W: A. Kawecka-Gryczowa (red.), Drukarze dawnej Polski od XV do XVIII w. (t. 3, cz. 1, Wielkopolska, s. 170-174). Wrocław-Warszawa-KrakówGdańsk: Zakład Narodowy im. Ossolińskich.

Sójka J.

1977d Regulus Wojciech. W: A. Kawecka-Gryczowa (red.), Drukarze dawnej Polski od XV do XVIII w. (t. 3, cz. 1, Wielkopolska, s. 209-217). Wrocław-Warszawa-Kraków-Gdańsk: Zakład Narodowy im. Ossolińskich.

Sójka J.

1977e Wolrab. W: A. Kawecka-Gryczowa (red.), Drukarze dawnej Polski od XV do XVIII w. (t. 3, cz. 1, Wielkopolska, s. 269-298). Wrocław-Warszawa-Kraków-Gdańsk: Zakład Narodowy im. Ossolińskich.

Topolski J. (red.)

1988 Dzieje Poznania (t. 1, cz. 1). Warszawa-Poznań: Państwowe Wydawnictwo Naukowe.

\title{
ARCHAEOLOGICAL EVIDENCE OF THE HISTORY OF PRINTING ON THE BASIS OF PRINTING HOUSES IN OSTRÓW TUMSKI IN POZNAŃ
}

\author{
S u m m a ry
}

During the archaeological excavations carried out between 2002 and 2014 in Ostrów Tumski (also referred to as the Cathedral Island) in Poznań there were pieces of type collected and identified, including twenty-nine letters (with eight italic and four ligatures, three of them also italic), thirteen punctuation marks and four numerals. Another twenty-one pieces were spaces, used in typography, whilst twelve pieces have been broken. eight have had ornamented faces, with decoration motifs including: flowers, leaves, a double palmette, and Sagittarius. They were meant for aesthetic purposes, either to create bordering, or to highlight and separate a text. These rectangular 
cube-shaped pieces of type were found together with a decorative matrix of a curved top of a crosier in shape.

A thorough analysis of manuscripts held by the Poznań Society of Friends of Sciences (hereinafter referred to as PTPN from Polish Poznańskie Towarzystwo Przyjaciót Nauk) helped to assume when particular ornaments were used and in which works published by the Academic Printing House they appeared. It has been observed that it was a double-stem leaf motif that had been used most frequently and for the longest period of time (1690-1738). Another motif appearing in the same publications was a "palmette" (1690-1723). The most significant variety of typepictograms has been used in calendars, where a motif of a Sagittarius was observed (1745-1778), a type collected during the excavations. The eighteenth-century calendars were meant not only for their nominal purpose, but they were also guidebooks on household, astronomy and medicine. Another identified decorative motif has been a crosier matrix which was used in Szeliga coat of arms - Mikołaj Ignacy Łukowski's, a prevost of Strzelno, coat of arms, which was published in printed sermon of 1735. In 1729 Pope Benedict XIII conferred on prevost Łukowski a title of prothonotary apostolic, together with the privilege of using bishopric insignia. This is why there were a galero with tassels, a mitre and a crosier observed in his coat of arms.

There was a clear concentration of typographic materials observed in the north-western area of Ostrów Tumski, close to the building of the Lubrański's Academy. According to written sources, between 1689 and 1780 the Academic Printing House operated there. However, some of the collected artefacts might have belonged to another printing house, operating previously in the same area, owned by the Wolrab family (1584-1610). It has been emphasised several times in various studies that typographic, decorative and illustrative materials used by the latter were continuously in use for printing by W. Regulus and his successors. In 1679 the printing house belonging to the latter was sold to Fr. W. Laktański, and in 1689 it became a property of the Lubrański's Academy.

The collection of type (together with analysed publications) constitutes a material evidence of the work of Poznań compositors and illustrates contacts the town had with German cities Wrocław and Frankfurt on the Oder, from where, according to written sources, typesetting materials were imported.

Translated by Lucyna Leśniak 